\title{
びまん性子宮平滑筋腫症に対する腹腔鏡補助下筋腫核出術の工夫
}

東京都済生会中央病院

大熊優子、塚田ひとみ、西山紘子、河西明代、小野寺成実、弟子丸亮太、岸 郁子

\section{Laparoscopically Assisted Myomectomy Technique for Diffuse Uterine Leiomyomatosis}

Yuko Okuma, Hitomi Tsukada, Hiroko Nishiyama, Akiyo Kawanishi,

Narumi Onodera, Ryota Deshimaru, Ikuko Kishi

Tokyo Saiseikai Central Hospital

\begin{abstract}
Objective: To assess the effects of the laparoscopically assisted myomectomy (LAM) procedure that we added to a previously reported technique for diffuse uterine leiomyomatosis.

Methods: In the previous technique, a longitudinal dissection was made at the midline of the uterus, and then the uterine wall was divided into two from the dissection site to effectively enucleate the myomas near the endometrium. We performed this technique after clipping the uterine artery temporarily under laparoscopy to reduce blood loss. Moreover, we did not use an energy device for enucleation near the endometrium to prevent heat damage.

Results: We performed this operation in two patients, with blood losses of 693 and $180 \mathrm{~g}$ and operation times of 334 and 327 minutes, respectively. Their intraoperative and postoperative courses were uneventful. One patient gave birth to a healthy baby. The other patient showed an improvement for hypermenorrhea.

Conclusion: The procedure we added to the previous technique was safe and effective. Further studies involving more patients are needed to examine pregnancy or menstrual outcomes.
\end{abstract}

Key words: diffuse uterine leiomyomatosis, laparoscopically assisted myomectomy, temporary uterine artery clipping

\section{【緒言】}

びまん性子宮平滑筋腫症（Diffuse Uterine Leiomyomatosis、以下DUL）は、小筋腫が子宮 頸部以外の筋層を占拠するまれな病態で、過多月 経の症状を呈し、不妊症の原因ともなる。筋腫は 内膜面に近接した筋層内に集中して発生するた め、漿膜面からの子宮筋腫核出術アプローチは容 易でなく、術中の多量出血、筋腫遺残や早期再発 のリスクがある ${ }^{1,2)}$ 。子宮温存は困難であるとされ ているが、2014年にNishidaらが子宮温存を試み る新しい術式を報告しだ”。この術式に工夫を加 え 2 名の患者を治療し、1 名は妊娠出産に至った ため両名の同意を得て報告する。

\section{【方 法】}

Nishidaらの術式では、まず開腹下で100倍希釈 バソプレシンを子宮に局注し、子宮を長軸方向に 内子宮口の位置まで半切して内腔を開放する。さ らに、子宮壁を断面から 2 層に切開し、漿膜側と 内膜側に分けて筋腫を核出する。筋層縫合はまず 内膜側と漿膜側の層を合わせ、ついで左右を縫合 する。DULと術式のイメージを図 1 に示す。

我々はこの術式に以下の工夫を加えた。すなわ ち 1 . 腹腔鏡補助下に手術を行うこと、2. 両側 子宮動脈を一時的にクリッピングすること（図 $2) 、 3$. 内膜側筋腫の核出にはなるべく電気メ スを使用せずメッチェンバウムなどの先細剪刀を 用いることである。 


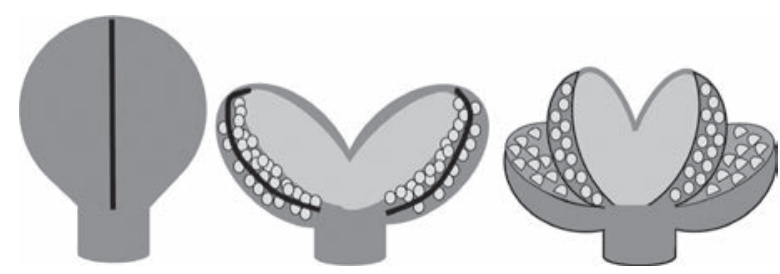

図 1 子宮半切術式のイメージ

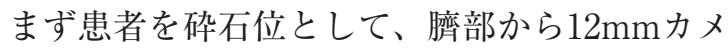
ラポートを挿入、腹腔内を観察後に約 $6 \mathrm{~cm}$ の下 腹部横切開を加え創保護材とキャップで気密性を 保ち、さらに両側下腹部に $5 \mathrm{~mm}$ 鉗子ポートを挿 入した。腹腔鏡下に前方アプローチの要領で広間 膜前葉を切開し子宮動脈本幹を同定・単離し、無 外傷性血管クリップで一時的に挟鉗した。次いで 下腹部創から可及的に子宮を体外へ挙上し、血管 クリップの位置を確認した。適応外使用であるこ との同意を得たうえで100倍希釈バソプレシンを 子宮に局注し、電気メスを用いてNishidaらの方 法で子宮を内膜側 2 層、漿膜側 2 層の計 4 層に分 割した。内膜側層の筋腫は内膜損傷を可及的に防 ぐため電気メスを使用せずメッチェンバウムにて 核出した。漿膜側層の筋腫核出は止血効果を優先 し電気メスを用いた。筋層縫合は全てモノフィラ メント吸収系を用い単結紮縫合を行い、漿膜面は baseball sutureとした。子宮を腹腔内に還納し、 瘉着防止剤を貼付した。腹腔鏡下に両側子宮動脈 のクリップを外し、止血を確認し閉創した。

\section{【症例】}

（症例 $1 ） 33$ 歳未経妊、既往歴は特になし。検診 で多発子宮筋腫と貧血（Hb $10.8 \mathrm{~g} / \mathrm{dl}$ ) を指摘さ れ、過多月経と挙児希望を主訴に受診し、経腟超
音波・骨盤MRI - 子宮鏡検査で粘膜下筋腫を含む DULと診断した。経過観察を希望されたが、徐々 に月経量が増加したことと妊娠に至らないことよ り、初診から 8 只目に子宮鏡下粘膜下筋腫切除 術を施行した。筋層内筋腫はそのまま遺残とした。 術後、一時的に月経量が減少したが、9 カ月後か ら再度過多月経を認めるようになった。この時の 骨盤単純MRI - 子宮鏡検查所見より、内膜面に近 接した筋層内筋腫に対して子宮鏡下手術は有効で ないと判断し、本術式を選択した。手術時間334分、 出血量693 g、切除筋腫核100個以上、重量は計 $143 \mathrm{~g}$ であった。術中回収した自己血 $220 \mathrm{~g}$ 、術前 貯血した自己血 $800 \mathrm{~g}$ の計 $1020 \mathrm{~g}$ を輸血した。子 宮腔内の瘉着防止目的で手術終了時に子宮内避妊 用具を挿入した。術後経過は問題なく第 5 病日に 軽快退院となった。過多月経と貧血は改善した。 術後 2 か月目に子宮内避妊用具を抜去し、6 6 月 の避妊期間を経て術後11か月目に自然妊娠に至っ た。他院で妊婦健診を受け特に問題なく経過して いたが、妊娠36週 3 日に陣痛発来のため緊急帝王 切開術を施行され、2672gの生児を得た。その際、 胎盤は抵抗なく娩出でき、また子宮漿膜面に筋層 のくぼみが認められたが明らかな菲薄化は認めら れなかった。術後 1 か月目に胎盤ポリープを疑う 所見が認められたが、出血なく血中hCG低下傾向 のため保存的加療にて経過観察となっている。(図 3 )

（症例 2 ）33歳未経妊、既往歴は特になし。過多 月経を主訴に受診し、重症貧血 $(\mathrm{Hb} 5.7 \mathrm{~g} / \mathrm{dl}$ ) の状態であった。性交未経験のため経直腸超音波 検査と骨盤単純MRI検查でDULと診断した。子 宮鏡検査では切除可能な粘膜下筋腫を認めなかっ た。6カ月間の GnRHアゴニスト投与による偽閉
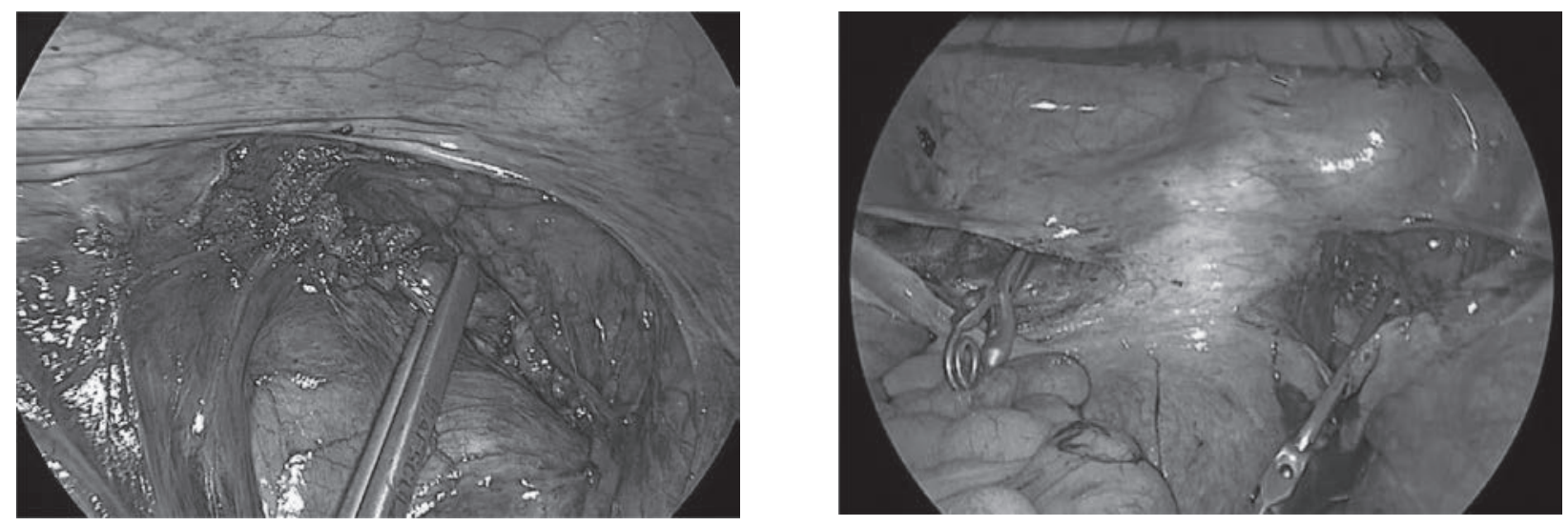

図 2 両側子宮動脈の一時的クリッピング 


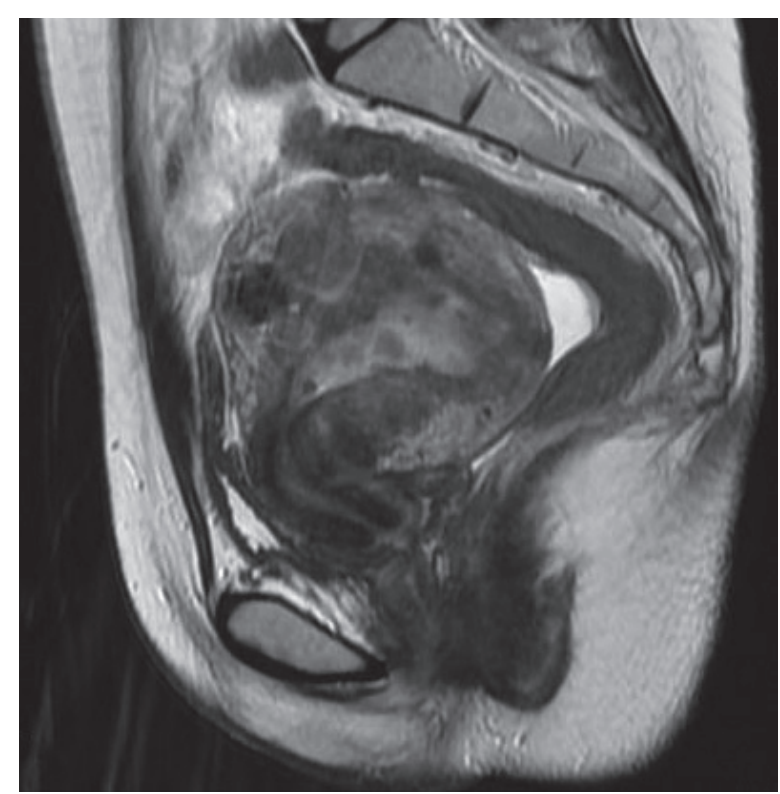

A

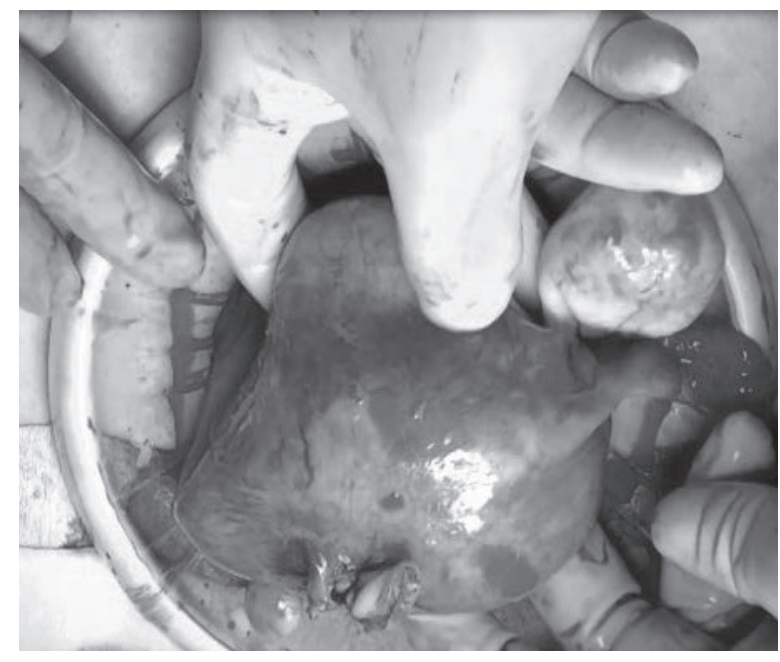

C

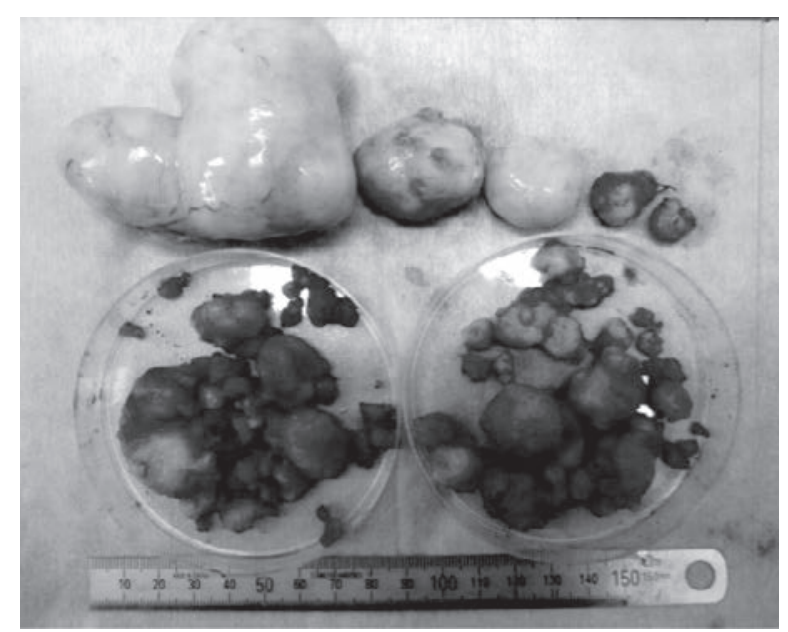

E

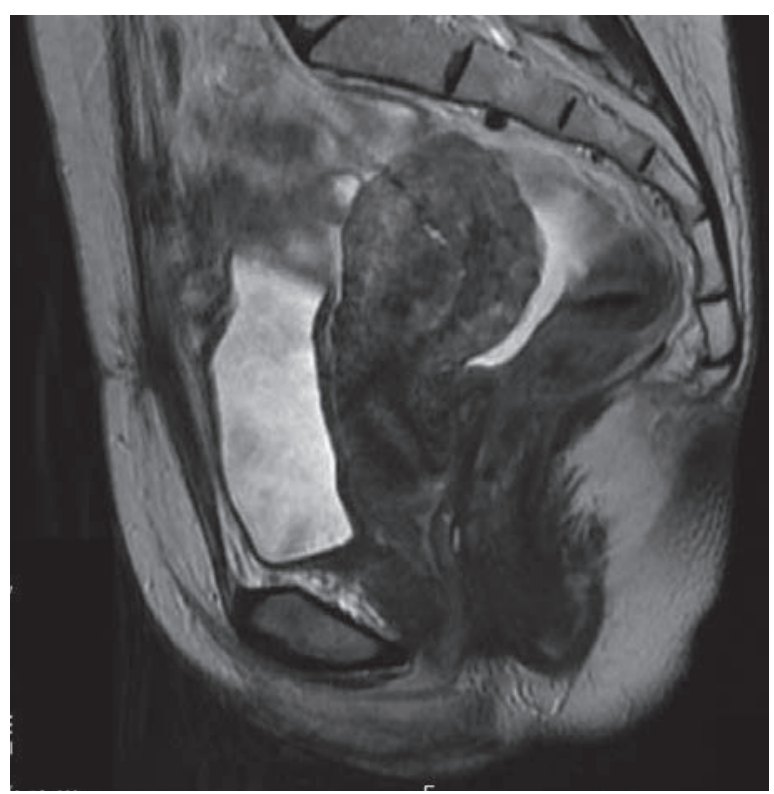

B

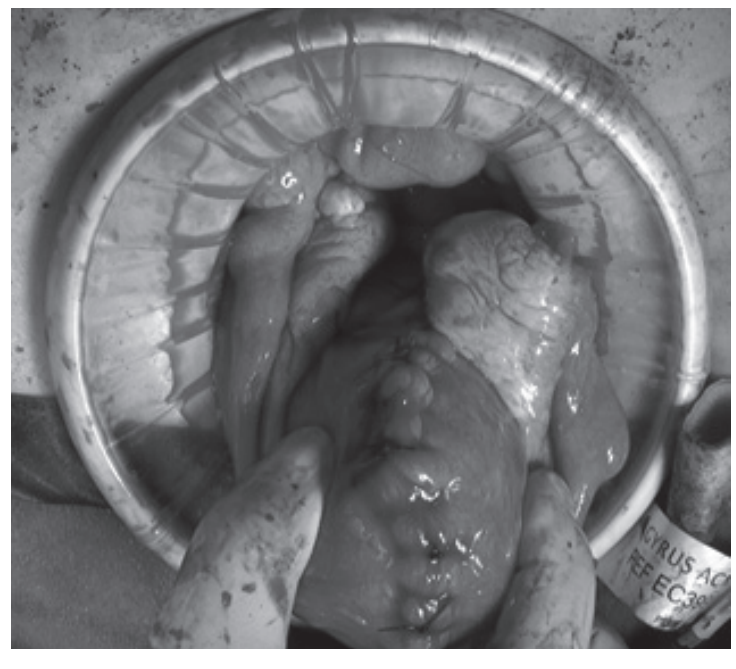

D

図 3 症例 1

A : 本術式術前の骨盤単純MRI（T2強調矢状断） B : 術後3力 月目の骨盤単純MRI（T2強調矢状断） C : 筋層内・粘膜下筋 腫核出前 $D$ : 縫合後 $E$ : 摘出標本 
経療法で一時的に症状は緩和されたが、偽閉経療 法終了の 4 力月後から月経が再開し、翌月には $\mathrm{Hb}: 8.3 \mathrm{~g} / \mathrm{dl}$ となったため低用量EP配合剤の周期 投与を開始した。しかし、9 周期終了後に $\mathrm{Hb}$ ： $5.4 \mathrm{~g} / \mathrm{dl}$ となり中止した。子宮温存手術を希望さ れたため、2 力月偽閉経療法を追加し、本術式を 施行した。手術時間327分、出血量 $180 \mathrm{~g}$ 、切除筋 腫核131個、重量は計55 gであった。術前貯血し た自己血 $800 \mathrm{~g}$ を輸血した。第 1 病日に 39 度の発 熱あり、抗生剂を第 3 病日まで投与継続した。発 熱以外の症状なく、第 6 病日に軽快退院となった。 手術終了時に子宮内避妊用具を挿入し、術後 6 日 目から 6 力月間偽閉経療法を再施行した。筋腫の 再発は必至であるため術後も月経コントロールが 必要と考元、偽閉経療法終了の翌月に子宮内避妊

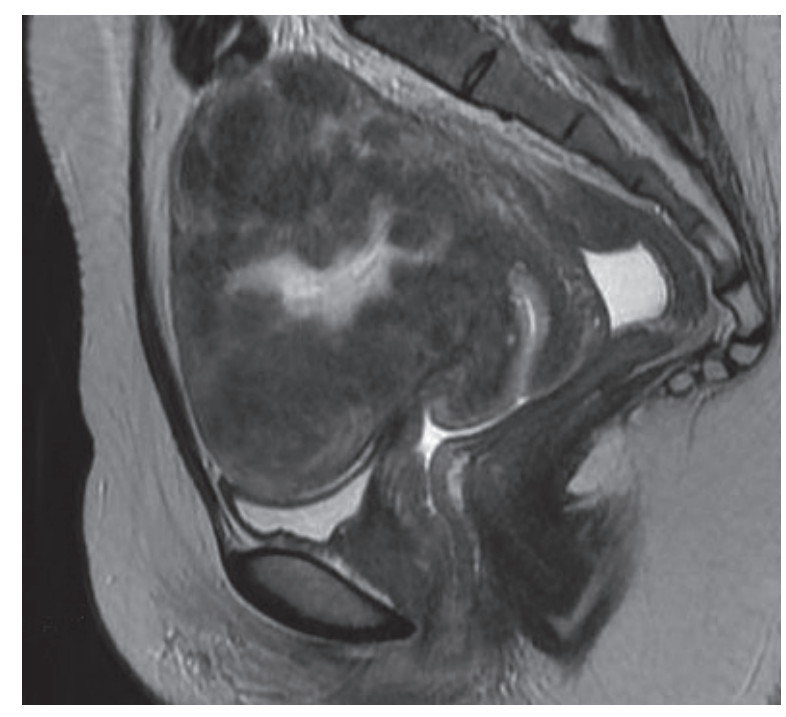

A

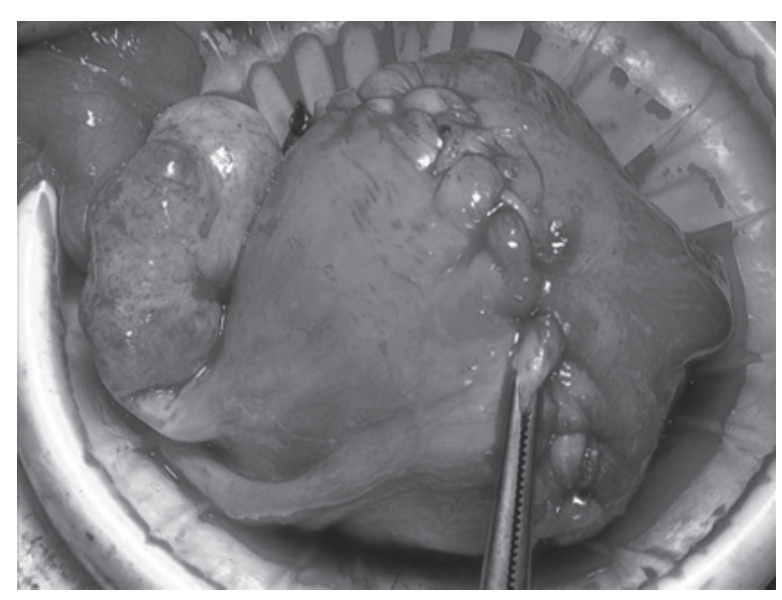

C
用具を抜去しジエノゲスト内服を開始した。術後 8 力月目の経直腸超音波検查で子宮筋腫再発が確 認されたが、多量不正出血などは認めておらず、 いずれ子宮内黄体ホルモン放出システムへの切り 替えを考慮している。(図 4)

\section{【考察】}

今回の 2 症例は、術後過多月経掞よび貧血は解 消し、このうち 1 例は妊娠し生児を得た。本術式 では、DULの特徴でもある内膜面近傍に集中し て発生する多数の筋腫を、効率よく確実に核出す ることができた。子宮を半切し筋層に埋没してい る多数の小筋腫を核出するため、摘出筋腫の総重 量に比べて術中出血量が多い印象はあったが、自 己血輸血を施行することで術中および術後経過は

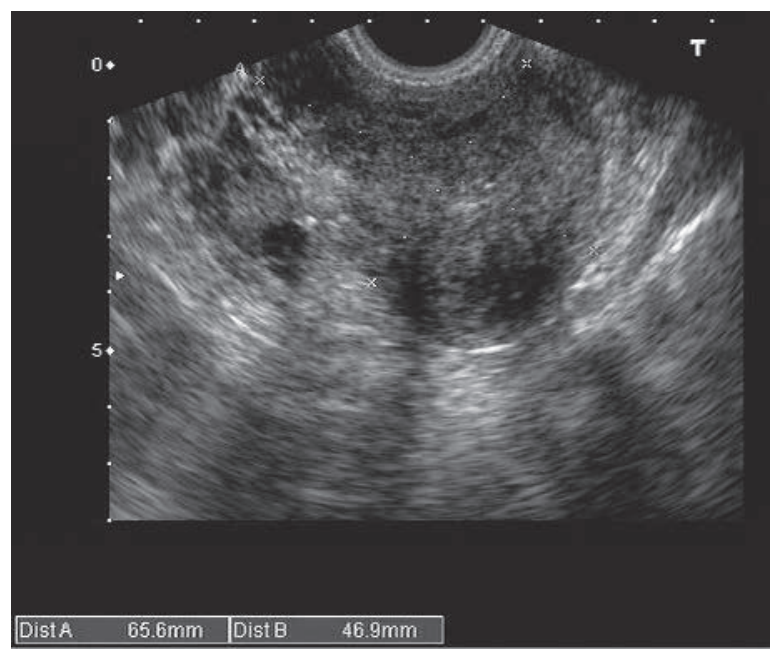

B

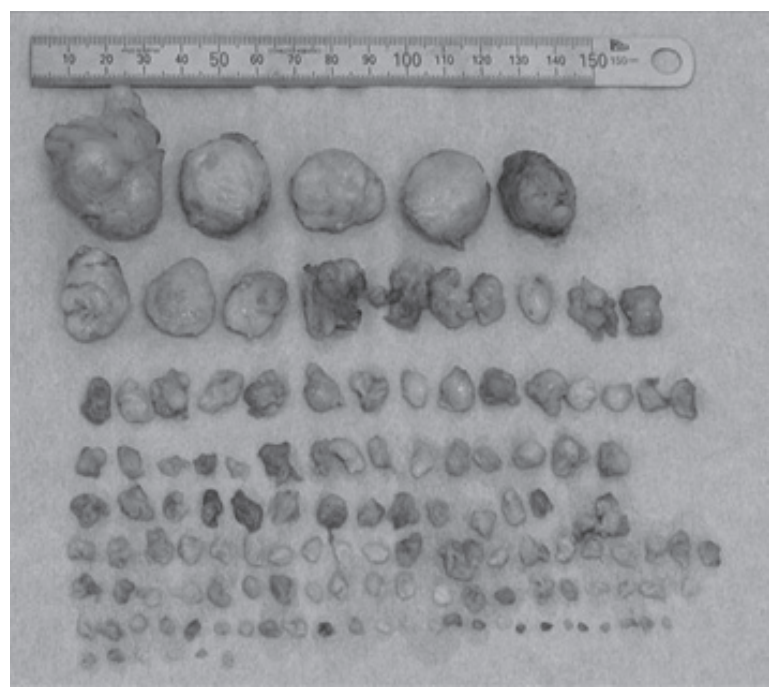

D 


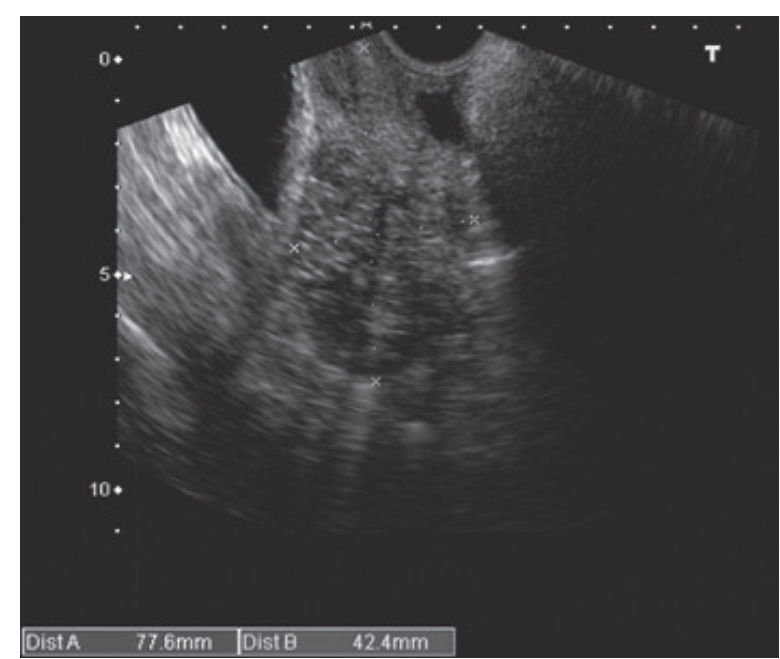

E

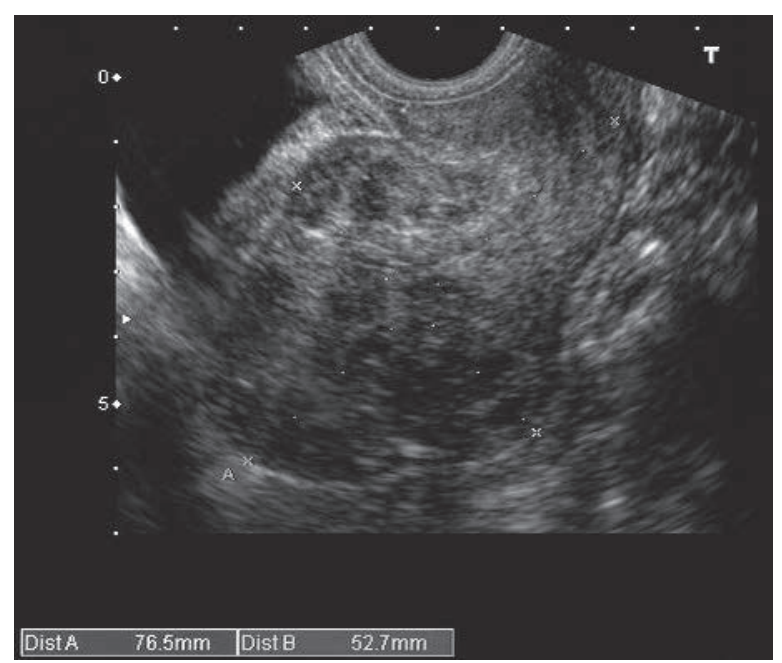

$\mathrm{F}$

図 4 症例 2

A : 術前の骨盤単純MRI（T2強調矢状断） B : 術前の経直腸超音波所見 C : 縫合後 D：摘出標本 $E$ ：術後3週目の経直腸超音波所見 $F:$ 術後 1 年目の経直腸超音波所見

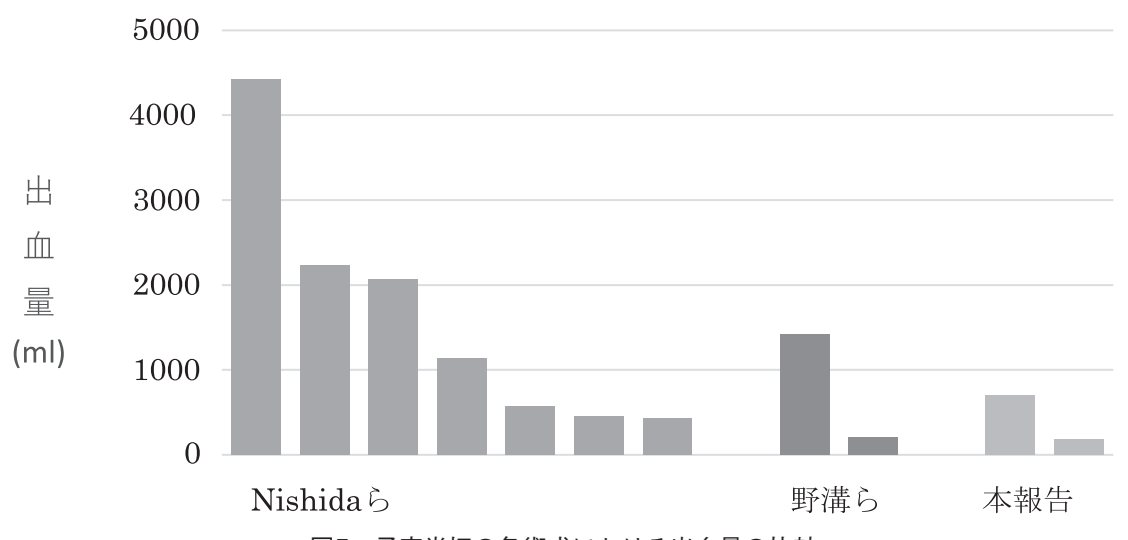

図5 子宮半切の各術式における出血量の比較

表1 子宮半切の各術式における出血量と手術時間

\begin{tabular}{|l|l|l|l|l|l|l|l|l|l|l|l|}
\hline & \multicolumn{4}{|l|}{ Nishida ら } & \multicolumn{3}{l|}{ 野溝ら } & \multicolumn{2}{l|}{ 報告 } \\
\hline 出血量 $(\mathrm{ml})$ & 4421 & 2230 & 2070 & 1130 & 570 & 450 & 428 & 1420 & 200 & 693 & 180 \\
\hline 手術時間 (分) & 407 & 280 & 320 & 275 & 288 & 210 & 212 & 392 & 182 & 334 & 327 \\
\hline
\end{tabular}

良好であった。妊孕性温存を考慮し、内膜面近傍 の筋腫核出にはできるだけ電気メスではなくメッ チェンバウムを使用して子宮内膜の損傷を可及的 に防ぐように留意した。両側子宮動脈を一時的に クリッピングすることで出血の少ない術野にする ことがこの手技を可能にしていると考えられた。 可及的多数の筋腫を核出することで、挙児希望の ある場合は妊娠成立後に残存筋腫によるトラブル を回避できる可能性があり、挙児希望がまだない 場合にも筋腫再発による月経随伴症状再燃までの 期間を延長できる可能性がある。妊娠中の子宮破
裂のリスクや出産時の癒着胎盤の可能性などが危 惧されるが、妊孕性温存・挙児希望の症例に対し て本術式は有用であると考えられた。

Nishidaらは子宮半切の術式を 7 例に施行、手 術時間中央值284分 (212 407分)、出血量中央值 $1614 \mathrm{~g}$ （428～4421 g) であった。3 例が妊娠し、 2 例は生児を得たが、1 例は自然流産となった

Nishidaら以前の妊孕性温存治療としては、以下 に示すように偽閉経療法 4.55 、子宮動脈塞栓術 ${ }^{6-8)}$ 、 子宮鏡下粘膜下筋腫切除術 $2,10,11$ などの有効性が 報告されている。Fedeleらは偽閉経療法後妊娠に 
至り、妊娠34週で緊急帝王切開術・子宮全摘術が 施行された 1 例を報告している ${ }^{4)}$ 。Purohitらの症 例は偽閉経療法後妊娠に至り、帝王切開術で 2 名 の生児を得ている ${ }^{5)}$ 。従って、偽閉経療法単独で の治療は治療後すぐ妊娠に至った症例には有効で ある可能性があるが、治療終了後早期に過多月経 などの症状が再燃する場合には他の治療法との組 み合わせが必要になると思われる。Kidoらの 1 例、Scheurigらの 6 例中 5 例、Kohらの 7 例は子 宮動脈塞栓術にて月経随伴症状の改善が認めら $れ^{6.8)}$ 、そのうちKohらの 1 例は治療の 5 か月後に 妊娠に至っている ${ }^{8)}$ 。Scheurigらの 6 例中 1 例は 治療が無効であり子宮全摘術が施行された7)。子 宮動脈塞栓術では子宮内膜の癒着を回避できる が、術後の卵巣機能不全や子宮性無月経の恐れが あり、挙児希望のある症例に対する適応は慎重に 選択する必要がある。Chenらは収束超音波治療 の有効性について報告しているが、現在日本では 子宮筋腫に対する保険適応がない9 。子宮鏡下粘 膜下筋腫切除術は、Yenらの 5 例、Shimizuらの 1 例、Mazzonらの1例で良好な治療結果が示され ており、上記 7 例のうち挙児希望のある 5 例全員 が妊娠・出産に至っている2,10,11)。しかし粘膜下筋 腫に限定した治療であるため、本報告の症例 1 の ように月経随伴症状がすぐに再燃することや、症 例 2 のように子宮鏡手術で摘出できる筋腫のない 場合もあり、必ずしもDUL症例での有効な術式 とならない。

野溝らは、挙児希望のあるDULの姉妹に対し て偽閉経療法後に開腹筋腫核出術を施行してい $3^{12)}$ 。子宮広間膜を穿通して10Frネラトンカテー テルで子宮頸部を絞扼し30分ごとに解除するとい う阻血の工夫を加えてNishidaらの子宮半切によ る術式を行う方法で、手術時間はそれぞれ392分、 182分、出血量は1420 g、200 gであった。1例は 妊娠・出産し、1例は妊娠に至らないものの月経 随伴症状の増悪を認めていない。我々の 2 症例で は子宮動脈本幹をクリッピングしている時間は症 例 1 で計151分、症例 2 で計194分であった。30分 ごとに確認したが、子宮筋の虚血を疑うような变 化は認めなかったため、クリッピングは子宮漿膜 の創部を縫合し終わるまで継続した。クリッピン グ解除後は子宮漿膜創部からの出血を少量認めた が止血に難渋することはなかった。

図 5 に子宮半切の 3 術式による出血量の比較 を、表 1 に各症例の出血量と手術時間を示す。症 例数が異なるため単純に比較できないが、阻血の
工夫を加えた術式では出血量の減少が期待でき る。手術時間・出血量 · 摘出筋腫重量の相関関係、 術後の妊娠出産率、術後の過多月経再燃率や再燃 までの期間などは症例数を増やして今後も検討し ていく必要がある。また、術後に妊娠に至った場 合にも切迫早産、子宮破裂、癒着胎盤、胎盤遺残 などのリスクが従来の筋腫核出術と比して上昇す るか否かも重要となる。

今回経験した 2 症例のうち、症例 2 のように将 来的に挙児希望はあっても、すぐに妊娠を希望し ない場合にはどのような方法で手術を行っても再 発は必至である。どの夕イミングで手術治療に踏 み切るかについては、挙児希望のある症例以上に よく検討する必要があり、この点も今後の課題と 考えられた。

本論文の要旨は第59回日本産婦人科内視鏡学会 において発表した。

全ての著者は開示すべき利益相反はない。

\section{【参考文献】}

1) Lapan B, Solomon L: Diffuse leiomyomas of the uterus precluding myomectomy. Obstet Gynecol 1979; 53: 82-84.

2) Yen CF, et al.: Successful pregnancies in women with diffuse uterine leiomyomatosis after hysteroscopic management. Fertil Steril 2007; 88: 1667-1673.

3 ) Nishida M, et al.: New myomectomy technique for diffuse uterine leiomyomatosis. J. Obstet. Gynaecol. Res. 2014; 40: 1689-1694.

4) Fedele L, et al.: Conservative treatment of diffuse uterine leiomyomatosis. Fertil Steril 2004; 82: 450453.

5 ) Purohit R, Sharma JG, Singh S: A case of diffuse uterine leiomyomatosis who had two successful pregnancies after medical management. Fertil Steril 2011; 95: 2434. e5-6.

6 ) Kido A, et al.: Uterine arterial embolization for the treatment of diffuse leiomyomatosis. J Vasc Interv Radiol 2003; 14: 643-647.

7 ) Scheurig C, et al:: Uterine artery embolization in patients with symptomatic diffuse leiomyomatosis of the uterus. J Vasc Interv Radiol 2008; 19: 279-284.

8 ) Koh J, et al. : Uterine artery embolization (UAE) for diffuse leiomyomatosis of the uterus: Clinical and imaging results. Eur J Radiol 2012; 81: 2726-2729.

9 ) Chen L, et al:: High-intensity focused ultrasound ablation for diffuse uterine leiomyomatosis: A case report. Ultrason Sonochem 2015; 27: 717-721. 
10) Shimizu Y, et al.: Successful pregnancy after gonadotropin-releasing hormone analogue and hysteroscopic myomectomy in a woman with diffuse uterine leiomyomatosis. Arch Gynecol Obstet 2009; 280: 145-147.

11) Mazzon I, et al. : Is 'cold loop' hysteroscopic myomectomy a better option for reproduction in women with diffuse uterine leiomyomatosis? A case report of successful repeated pregnancies. J. Obstet. Gynaecol. Res. 2015; 41: 474-477.

12）野溝万吏、他：子宮びまん性平滑筋腫症を認めた姉 妹例、産婦の進歩、2013； $65 ： 40-45$.

投稿日：2019年11月 6 日

採択日：2020年 1 月 20 日 